\title{
The Temporality of Sculptural Viewing in Hemsterhuis' Lettre sur la sculpture
}

\section{Jason Gaiger}

According to Goethe's own account of his participation in the disastrous Prussian military campaign of 1792 against revolutionary France, despite witnessing at first-hand the effects of injury, appalling weather, and spreading dysentery on the retreating troops, his thoughts turned to the Lettre sur la sculpture by the Dutch philosopher Frans Hemsterhuis (1721-1790), published over 20 years earlier in $1769 .{ }^{1}$ Observing that he could not fully assimilate Hemsterhuis' ideas without recasting them in his own terms, he sought to capture the central argument of the Lettre in the following way:

The beautiful and the pleasure to which it gives rise is - as he expressed it experienced when we perceive and comprehend the greatest number of ideas effortlessly in a single moment of time. I have to put this differently: we experience the beautiful when we apprehend something living in accordance with the lawfulness of nature in its highest activity and perfection, and we are thereby stimulated to recreate, becoming aware of ourselves too as alive and supremely active. ${ }^{2}$

That Hemsterhuis' conception of beauty as the maximum number of ideas apprehended in the minimum period of time still resonated with Goethe so many years later testifies to the remarkable reception accorded to his work, which was read and discussed beyond his native Holland by many of the leading figures of the European Enlightenment. While Hemsterhuis' main contribution was to the domain of moral philosophy, his short Lettre sur la sculpture attracted considerable attention not only for its concise articulation of an original theory of aesthetic experience but for the unusual methods the author employed to substantiate his views. 
In many respects Hemsterhuis is a representative figure of the eighteenthcentury 'republic of letters'. Born into an academic family - his father Tiberius was a renowned philologist - he nonetheless never held a university post. Having been passed over for a professorship at Franeker University in 1755, he instead took up a position with the State Council of the Netherlands at the Hague, rising to the rank of First Secretary in $1769 .{ }^{3}$ His writings were the result of private study, personal friendships and extensive correspondence, which he carried out alongside his official duties for the state. It is not coincidental that his first published works, including the Lettre sur la sculpture (1769), the Lettre sur les désirs (1770) and the Lettre sur l'homme et ses rapports (1772), were composed in response to requests from specific correspondents, or that he subsequently adopted the discursive structure of the Platonic dialogue in works such as Sophyle (1778), Aristée (1779), and Simon ou les facultés de l'âme (1787), which allowed him to present his ideas in the form of a critical exchange of views. $^{4}$

Most of Hemsterhuis' life was spent in the Netherlands, but he did travel to Germany, where he met figures such as Jacobi, Goethe, Wieland, and, perhaps most significantly, Herder, who played an important role in disseminating knowledge of his writings. Herder does not directly refer to Hemsterhuis in his book Sculpture: Some Observations on Shape and Form from Pygmalion's Creative Dream (1778), which both develops and contradicts some of the central claims of the Lettre sur la sculpture, but we know that he had sought to arrange for the Lettre to be translated into German soon after its original publication. ${ }^{5}$ Herder himself translated the Lettre sur les désirs for the journal Der Teutsche Merkur in 1781, and his essay 'Liebe und Selbstheit', published in the same journal, was presented as a response to its 'richness of ideas' and the 'beauty and rarity' of their expression. ${ }^{6}$ In France, Diderot wrote an extensive commentary inside a special large-format exemplar of the Lettre sur l'homme that had been given to him personally by Hemsterhuis, returning it to the philosopher in $1774 .{ }^{7}$ All of Hemsterhuis' published work was written in French, and the first complete edition of his Oeuvres philosophiques appeared posthumously in Paris in 1792, edited by Hendrick J. Jansen. ${ }^{8}$ However, it was undoubtedly in Germany that his 
writings were most widely distributed and most intensively discussed. This is also true of the Lettre sur la sculpture, which was the subject of a long and detailed review in 1771 by the philosopher Christian Garve, today known primarily for his critical engagement with the work of Immanuel Kant, and a shorter but equally insightful analysis by Moses Mendelssohn, who drew a connection between the position Hemsterhuis defends and his own longstanding dispute with Lessing over his account of the relation between painting and sculpture in the Laocoön. ${ }^{9}$

The critical reception of Hemsterhuis' writings was not limited to his contemporaries: his work continued to be read through until the early years of the nineteenth century, providing what Heinz Moenkemeyer terms fermenta cognitionis for writers and philosophers associated with Early German Romanticism. ${ }^{10}$ Herder is a key transitional figure here, of course, but many aspects of Hemsterhuis' thought, including his emphasis on the role of love and friendship, the significance he accorded to the role of intuition, and his unfulfilled yearning for a deeper Platonic conception of unity, proved highly congenial to thinkers such as Novalis and Friedrich Schlegel, who readily acknowledged their indebtedness to the Dutch philosopher. ${ }^{11}$ As late at 1808 , in his Lectures on Dramatic Art and Literature, August Wilhelm Schlegel sought to establish a connection between his own distinction between 'antique' or 'classical' art and what he termed 'modern' or 'romantic' art and Hemsterhuis' observations in the second part of the Lettre sur la sculpture, in which he argued that whereas the spirit of the ancients was essentially 'sculptural', the spirit of the moderns is 'painterly'.12 Nonetheless, there is broad agreement that Hemsterhuis' influence rapidly waned in the course of the nineteenth century, thereafter receding into obscurity. With reference to the Lettre sur la sculpture, Moenkemeyer claims that 'Hemsterhuis' views are today only of historical interest, mainly because they attracted the attention of Goethe and other prominent writers'. ${ }^{13}$ Similarly, Jacob van Sluis contends that "his works should be studied as belonging to a closed phase of philosophical and cultural development' and that 'Hemsterhuis' importance is therefore essentially historical'. ${ }^{14}$ 
Recent scholarship has made Hemsterhuis' writings accessible again to nonspecialists. The new 'critical edition' of his Oeuvres philosophiques, edited by van Sluis and published by Brill in 2015, provides detailed notes and a comprehensive scholarly apparatus. ${ }^{15}$ Sluis prints the eighteenth-century German translation in parallel with the original French text in order to acknowledge the historical significance of the German reception of Hemsterhuis' ideas, and for the Lettre sur la sculpture he also includes the comments by Garve that had been incorporated into Jansen's edition. A publication of the Lettre sur la sculpture in an affordable softcover edition was made available in 1991 as part of the series of key works on aesthetics published by the École nationale supérieure des Beaux-Arts. ${ }^{16}$ This was followed by an Italian translation in 1994 in the series Aesthetica, which fulfils a similar function, supported by valuable explanatory essays and notes, and a Spanish translation in 1996 in a volume dedicated to Hemsterhuis' Escritos sobre estética, which also includes his dialogue Simon. ${ }^{17}$ Now, in a complete English version for the first time, we have Peter Dent's precise and elegant translation for this volume of the Sculpture Journal. ${ }^{18}$

The availability of the Lettre sur la sculpture, both in the original French and in translation, allows us to decide for ourselves whether the text is of 'closed' historical interest or whether it can still speak to current concerns. ${ }^{19}$ In this essay, I want to defend an alternative view that draws on the critical debates generated by the text, both among Hemsterhuis' contemporaries and in more recent scholarship, in order to identify what I see as the most challenging and thought-provoking features of his position. In particular, I aim to show that there is a tension between the rather conventional classicist assumptions that Hemsterhuis sets out to defend and the specific arguments and resources that he deploys in order to establish his conclusions. His analysis of the temporality of sculptural viewing directs attention to the contribution made by the viewer in establishing meaningful part-whole relations and forces us to think harder about what is involved in apprehending a plurality of parts as a unity or what he terms a 'totality'. This, in turn, bears directly on the long-standing question as to 
whether there are distinctive characteristics that distinguish sculptural from pictorial viewing, a question that is far from resolved in present-day discussions.

The relation between intensity and duration

The Lettre sur la sculpture is dated 20 November 1765 and addressed to the Amsterdam banker Theodore de Smeth, who was also the addressee of Hemsterhuis' earlier Lettre sur une pierre antique, written in 1762 but not published until after the author's death. ${ }^{20}$ Whereas the Lettre sur une pierre antique is an occasional piece, describing an engraved amethyst in de Smeth's collection, the Lettre sur la sculpture has good claim to be Hemsterhuis' first significant contribution to philosophy, laying the foundation for the future direction of his thought. Hemsterhuis himself arranged for the letter to appear in print a couple of years after it was written. The short text, little more than a pamphlet, was placed in the hands of the Amsterdam-based publisher, MarcMichel Rey, who had garnered a reputation for printing books by Enlightenment philosophers that had been proscribed in France, including major works by Rousseau, Diderot and Voltaire. In its published form, the Lettre is accompanied by two plates. These reproduce a number of drawings made by Hemsterhuis himself that play a central role in the argument he puts forward. ${ }^{21}$ The text is not marked by sub-divisions, but it clearly falls into three separate sections. The first presents Hemsterhuis' reflections on 'the purpose, the principle and the perfection of sculpture' on the basis of a more general theory of the arts, or, at least, those art forms that have 'a direct relation with the organ of sight' [L: 31]. A second, shorter section provides a highly compressed historical survey of the variant approaches to sculpture adopted by different peoples at different times, while the final section returns to the issues raised in the first part of the letter and makes some concluding observations concerning essential differences between sculpture and painting.

The core of the letter - and its principal claim to originality - lies in Hemsterhuis' defence of the thesis that 'the beautiful in all the arts should give us the greatest 
number of ideas possible, in the briefest span of time possible' [L: 39]. In accordance with the 'esprit géométrique' [L: 52] of the modern age, he formulates this thesis in quasi-mathematical terms as a ratio to which artworks can approximate to a greater or lesser degree insofar as they achieve an appropriate balance between two quantitatively measurable factors. However, if we ask what this formula adds to our understanding of sculpture, it is difficult to provide a satisfactory answer. It might initially appear simply to be a recasting of the familiar idea of 'unity amidst variety' dressed up in mathematical form. ${ }^{22}$ As early as 1725, the philosopher Francis Hutcheson had argued in his An Inquiry Concerning Beauty, Order, Harmony, Design that:

what we call beautiful in objects, to speak in the mathematical style, seems to be in compound ratio of uniformity and variety: so that where the uniformity of bodies is equal, the beauty is as the variety; and where the variety is equal, the beauty is as the uniformity. ${ }^{23}$

However, it is important to note that Hutcheson's account of beauty, which remains indebted to Locke's theory of ideas, lacks any reference to the temporality of aesthetic experience. For Hutcheson, the mere presence of unity amidst variety is sufficient to produce in us the idea of beauty, just as the detection of sugar by the tongue causes us to have the idea of sweetness. As he puts it: 'The internal sense [of beauty] is a passive power of receiving ideas of beauty from all objects in which there is uniformity amidst variety.'24 By contrast, Hemsterhuis directs attention to the active role of the observer in bringing together and combining a multiplicity of successively apprehended parts. Although he maintains that the complexity of the ideas expressed by an artwork and the duration required for their apprehension stand in inverse proportion - and he is thus, in a sense to be further specified, hostile or resistant to duration, which he treats as a minima - he nonetheless makes time into a central factor: the traditional concept of 'unity' is identified as essentially temporal since it is an achieved rather than a fixed characteristic, something that only emerges in the experience of the viewer. 
The originality of Hemsterhuis' approach is obscured by his apparently unshaken commitment to the central presuppositions of classicist art theory. Right at the outset of the Lettre sur la sculpture, he declares that the purpose of art is not simply to imitate to nature but to go beyond it, and that it is only insofar as we understand what it means for art to 'surpass' nature that we can grasp what is meant by beauty [L: 31]. ${ }^{25}$ We also find Hemsterhuis insisting on the primacy of contour or outline over both the distribution of light and shade and the role of colour - which is dismissed as 'nothing more than an incidental quality' (une qualité accessoire) - and placing great emphasis on the requirement that sculpture possess a unified and stable form that can be readily apprehended by the viewer [L: 32]. The conclusion to the Lettre offers a rather bland restatement of the view that 'the unity or simplicity of the subject, and the fluid and fine quality of the overall contour, constitute in sculpture the principal foundations' and Hemsterhuis does not shy away from issuing a series of prescriptions, including the avoidance of complex multiple-figure compositions, the minimal use of drapery, and even the inclusion of part of a column or vase 'whose regularity might make the beautiful irregularity of the figure even more striking' [L: 54-5].

Although all of these proposals can be found in standard academic teaching, they would have been familiar to Hemsterhuis' contemporaries above all through the writings of Johann Joachim Winckelmann, whose Thoughts on the Imitation of Greek Works of Painting and Sculpture (1755), gave fresh impetus to the idea that the artist should be guided by the concept of 'a more beautiful and a more perfect nature' (eine schönere und vollkommene Natur), which is revealed in exemplary fashion in the works of the ancient Greeks. ${ }^{26}$ There are many striking points of congruity between the Lettre sur la sculpture and the position defended by Winckelmann. The historical second part, in particular, bears close comparison with the work of the German art historian. ${ }^{27}$ Thus, for example, Hemsterhuis contrasts the sculpture of the Greeks, who sought 'to embody the greatest possible beauty' and 'to surpass nature herself' [L: 46-7], with the work of other peoples such as the Etruscans, who 'considered nature as a limit and a boundary of perfection beyond which there was nothing' and were led to adopt 
'servile imitation as a goal' [L: 48]. If we are to identify what is of lasting interest in the Lettre, we therefore need to look beyond these standard formulations, which appear to be indebted to Winckelmann and other proponents of a neoclassical aesthetics. By directing our attention instead to the unusual methods that Hemsterhuis deploys in order to justify his views, we can examine whether this, in turn, results in a significant modification or inflection of otherwise familiar tenets of eighteenth-century neo-classicism.

Hemsterhuis' deployment of a drawing of a cone (fig. 1), marked to show some of the different angles from which it can be viewed and the resulting visible points on its surface, provides an economical means of establishing that any one viewpoint is necessarily partial. The recognition that the surface of a threedimensional object will appear differently when viewed from different positions can be traced back at least as far as Alberti. ${ }^{28}$ Hemsterhuis observes that only the art of sculpture, which represents an object in the round, can provide a 'perfect imitation' that encompasses all of its contours and that this suffices to establish the superiority of sculpture over painting and the other visual arts [L: 33]. At this stage in his argument, he seems to identify the idea of a perfect imitation with a mere duplicate or copy. The restrictive focus on the plurality of contours afforded by an object when it is seen from different perspectives, to the exclusion of light and shade and the use of colour, leaves no room for the idea that an artwork, although necessarily selective in the features it represents, can nonetheless effectively bring the fullness of an object to mind by suggesting where it does not directly depict, relying on the viewer's projective capacities to fill out and complete what is otherwise hidden or occluded from view. However, in the long endnote (a), appended to the Lettre, in which Hemsterhuis considers verse passages by Homer and Lucan that bring together things that are otherwise remote from each other - such as gods and mortals - he argues that in the case of arts that 'employ signs and words', that is to say poetry, oratory and other art forms that use language as a medium, 'the expression of a thought acts on the reproductive faculty of the mind (le faculté reproductive de l'âme)' [L: 60]. Here he acknowledges that the reader must grasp for herself a complex set of relations and conjoin disparate ideas within a single mental image. 
The first step towards recognition that the mind also has an active role to play in the appreciation of works of visual art - and the point at which the Lettre sur la sculpture veers off in an unexpected direction - is to be found in Hemsterhuis' seeming digression into the subject of children's drawings. With reference to a picture of a horse made for him by a young child who, we are told, had not yet been given instruction in the art of drawing, Hemsterhuis observes that:

in truth nothing was lacking; one found there all the parts (toutes les parties), even down to the nails of the horse shoes, but at the same time neither the mane nor the tail were in the proper place. I brought the child with its drawing before a real horse, and he seemed astonished by the fact that I did not see a perfect resemblance. [L: 33]

Hemsterhuis notes that although 'all the parts' of the horse are included in the depiction, the child is not yet able to discern their proper order or what we might term their internal relationship to one another. He seeks to find an explanation for this in 'the application of the rules of optics to the structure of our eye' [L: 334]. He starts out by observing that we are unable to focus on a plurality of visible points simultaneously but must instead must move our gaze along the contours of an object, with the result that different points are viewed successively. Since the complete object cannot be seen all at once with sufficient clarity, we should acknowledge that the mind makes the connection between all of these elementary points (l'âme fait la liaison de tous ces points élémentaires)' and that it is only at the end of this process that we are able to acquire 'the idea of the whole contour (l'idée de toute la contour)' [L: 34]. He goes on to observe that 'it is undoubtedly the case that this connection is an act for which the mind requires time (il est certain que cette liaison et un acte où l'âme emploie du temps)' [L:34]. The child's lack of experience reveals itself in his haphazard viewing of the different parts of the horse, his tendency to dwell on 'the more heterogeneous points of the object', and an inability to synthesise the parts into a properly ordered whole [L: 34]. Although the drawing gets many of the details right, such 
as the nails on the harness and on the horse's shoes, the child is unable to represent 'the local relation that these parts have amongst themselves' [L: 34].

What can we take away from this discussion? Hemsterhuis' appeal to the rules of optics is grounded, of course, in the knowledge that was available to him in the mid-eighteenth century. In particular, he seems to have been guided by his familiarity with the work of his friend and compatriot, Petrus Camper, whose Dissertatio Optica de Visu (Dissertation on the Optics of Vision) was published as his doctoral thesis in Leiden in 1746. Scientific research has confirmed the observation that visual acuity is determined by the anatomical structure of the human eye and that it is only within foveal vision that we see with any sharpness. Recent studies have shown that the human visual processing system is characterised by brief 'fixations' on specific points that typically last for 200300 milliseconds before the eye moves to a new fixation. ${ }^{29}$ Hemsterhuis is therefore correct to claim that we are unable to focus on a plurality of visible points simultaneously and that vision is essentially dynamic. On the other hand, there is little evidence to support his contention that the eye moves in an ordered way along the contours of an object. Instead, as the development of eyetracking technology has confirmed, the movement of the eye is characterised by step-wise jumps or leaps, termed 'saccades'. The eye moves from fixation point to fixation point in a discontinuous manner rather than proceeding continuously along the internal or external contours of an object. ${ }^{30}$ Even with the introduction of this important qualification, however, the conclusion that Hemsterhuis wishes to defend still stands: some form of higher-order mental processing is required in order to bring a plurality of visible points into a unity, and this 'act' necessarily that takes place over time. It might seem to us that we apprehend the various parts of an object instantaneously, but the ability to identify the 'connection' (liaison) between a plurality of points goes beyond what is directly given to us in experience.

In order to investigate these ideas further, Hemsterhuis carries out what he terms an 'experiment' (expérience) [L: 34]. This consists in showing several individuals two drawings (figs. $2 \mathrm{~A}$ and $2 \mathrm{~B}$ ), which depict two different vases, and 
asking them to say which they find the more beautiful. Hemsterhuis reports that this resulted in unanimous agreement that vase $A$ is more beautiful than vase $B$, and he places particular emphasis on the case of a 'man of good sense' without specialist knowledge of the arts who nonetheless declared that he was 'more powerfully impressed' (plus fortement affecté) by the first of the two vases [L: 34]. Although Hemsterhuis does not state this explicitly, the operative assumption behind the comparison seems to be that vase $\mathrm{A}$ is more ordered or coherent in the arrangement of its parts than vase $B$, and that this should enable the viewer to apprehend its form more quickly. As an aid to the reader, Hemsterhuis places letters at various points on the outline of each of the two vases. Since both drawings are marked with the same number of letters, this is intended to support his claim that despite the differences in their overall shape both vases possess the same 'quantity of visible points'. Here he is not yet concerned with the relation or connection between these points since, as we have seen, it is the liaison itself that he seeks to analyse into its constituent factors. The first factor, which he terms 'intensity' (intensité), is simply the quantity of visible points possessed by each of the outline drawings [L: 35]. On the assumption that this is identical for both vase $A$ and vase $B$, he is able to isolate a second factor, which he terms 'duration' (durée): this is the amount of time it takes the viewer to connect the visible points together in each case, or, as he also expresses it, the time it takes to acquire 'an idea of the entirety' (une idée du total) [L: 35]. By a simple process of exclusion, if the quantity of visible points is the same in both cases, then the difference between the two drawings resides in the rapidity with which the viewer can synthesise the parts into an ordered whole. He therefore concludes that the explanation for the declared preference for vase A over vase B is that it allows the viewer to connect its visible points more quickly and so 'acted with greater speed (plus de vélocité) on the mind' [L: 35].

From these observations, Hemsterhuis moves directly to his broader conclusion that it follows in a quite mathematical fashion, that the mind judges more beautiful, that of which it can form an idea in the shortest space of time' [L: 35]. An obvious objection here is that even in Hemsterhuis' simplified outline 
drawings it is impossible to ascertain whether the two vases possess the same quantity of visible points. If this is not to be an arbitrary stipulation, the experiment would have to be carried out using simple shapes or patterns rather than such elaborate designs. Equally problematic is Hemsterhuis' assumption that aesthetic experience can be analysed into just two factors: intensity and duration. Again, the examples appear ill-chosen for this purpose. The handles of both vases are heavily ornamented, the neck and base are richly fluted, and each presents a different depicted scene on its main body: the battle between Hercules and Hippolytus on vase A, and a seascape on vase B. This level of complexity makes it extremely difficult to identify which features of the vase the viewers are responding to in each case. In his defence of what he terms Hemsterhuis' 'aesthetic experiments', Peter C. Sonderen maintains that Hemsterhuis 'tries to explain an aesthetic judgment by means of an hypothesis and an experiment, that is to say, by means of the experimental method, as it was conceived of during the eighteenth century'. ${ }^{31}$ However, Hemsterhuis' approach is far less rigorous and systematic than this would suggest. It is not merely that a single pair of examples provides an uncertain basis on which to draw generalised conclusions: the 'experiment' itself fails to provide a means of distinguishing the relevant variables. I shall return to this point at a later stage when I consider the criticisms put forward by Garve and Mendelssohn, for it turns out that both 'intensity' and 'duration' permit of further analysis and that, contrary to Hemsterhuis' own assumptions, they cannot be treated in strictly quantitative terms.

Hemsterhuis himself anticipates a further objection, which is more easily answered. He recognises that it follows from the principle he has formulated that we should 'prefer a single black spot on a white background to the most beautiful and richest of compositions' [L: 35], since this would allow us to apprehend an idea instantaneously, albeit a rather uninteresting one. He therefore modifies his position to acknowledge that we naturally wish 'to have a large number of ideas in the shortest possible span of time' [L: 35-6]. He subsequently takes this argument a step further by replacing this claim with the observation that we desire to have the greatest possible number of ideas within the shortest possible 
period of time. The result of these reflections is captured in the following statement, which I cite here in Dent's translation and in the original French:

the beautiful in all the arts should give us the greatest number of ideas possible in the briefest span of time possible.

le beau dans tous les arts nous doit donner le plus grand nombre d'idées possibles, dans le plus petit espace de temps possible. [L: 39]

On this final or definitive formulation of Hemsterhuis' basic principle, the number of ideas is identified as a maxima while the amount of time is identified as a minima. This can be expressed as a ratio, with the number of ideas set against the amount of time required for their apprehension. Hemsterhuis recognises that what he terms the 'optimum' - the achievement of a perfect balance between these two requirements - can nonetheless be achieved in different ways [L: 40]. It is this argument that forms the basis for his analysis of the differences between sculpture and painting: in the case of sculpture, rapidity of apprehension takes precedence, whereas in painting we place greater value on the number and complexity of ideas. I shall examine Hemsterhuis' proposals in detail in the next section, but it is worth pausing here to consider the extent to which he has already departed from the classicist assumptions that he set out to defend.

I have already observed that Hemsterhuis begins the Lettre by declaring his allegiance to the central orthodoxies of neo-classical art theory. He takes it as given that art should 'surpass nature' and that it is only though examining what it means to 'outdo her and go beyond her' (ce renchérir sur elle et de la surpasser) that the meaning of beauty can be understood [L: 31]. This conception of the higher purpose of art is fully compatible with the classicist appeal to the beau idéal, the idea that the artist should seek to improve nature through reference to an ideal of perfection that is grasped by mind alone. However, when towards the end of the first section Hemsterhuis returns to the claim that art can surpass nature, he offers a markedly different justification: 
it is easy to understand from everything that I have just said, that it is quite possible, in so far as beauty is concerned, to surpass nature; since it would be a truly exceptional coincidence that would put a certain number of parts in such a combination that it might deliver this optimum that I desire, and that is analogous, not to the essence of things, but to the effect of the relationship that exists between things and the construction of my senses (l'effet du rapport qu'il y a entre les choses et la construction de mes organes). [L: 41]

Hemsterhuis' point is that the achievement of an optimum balance between the quantity of ideas and the time taken for their apprehension is only rarely to be found in ordinary experience and that his definition of beauty therefore allows us to understand why successful works of art should be seen as outdoing or going beyond nature: the constituent parts are organised in such a way that the viewer can apprehend even particularly dense or complex content as a unity with unusual speed or facility. Nonetheless, as the second part of the passage makes clear, Hemsterhuis relinquishes any residual appeal to the neo-Platonic idea that the artist has special insight into the 'essence' of things, the eternal forms or patterns that underlie experience. In its place, he offers a radically subjectivist interpretation of aesthetic appreciation in which beauty is located in the 'relationship' (rapport) between external objects and their apprehension through the senses. Not only is the perception of beauty dependent on the way in which the world is revealed to us through the particular configuration of our sensory organs, the very idea of beauty itself turns out to be sense-dependent. Hemsterhuis maintains that if you change the essence of our senses, or the nature of their constitution, all of our current ideas of beauty will be immediately reduced to nothing' [L: 41]. Indeed, he goes on flatly to contend that 'the beautiful does not have any reality in itself (le beau n'a aucune réalité dans soimême)' [L: 42]. Although Hemsterhuis retains the idea that art can surpass nature, he abandons the classicist reliance on the concept of ideal form in favour of a thoroughly naturalised account of beauty that allows him to analyse those features of works of art which produce 'effects' that are continuous with 
everyday experience but are also heightened or intensified in ways that we have come to value. ${ }^{32}$

\section{The problem of application}

Up to this point I have focussed on Hemsterhuis' attempt to give precision to his core thesis - that beauty consists in the maximum number of ideas apprehended in the minimum amount of time - and I have sought to show that the unusual strategies he deploys in order to establish this thesis have revisionary consequences. I now want to turn from the problem of grounding to the problem of application: how does Hemsterhuis establish the relevance of this thesis to specific art forms and what we can learn from its application in particular cases?33 Although Hemsterhuis makes reference to a variety of arts, including poetry, music and oratory, his real concern is clearly to distinguish the kinds of achievements that are proper to sculpture from those that are proper to painting. In what turns out to be a characteristically complex presentation of his views, he initially draws a distinction internal to sculptural practice, which he then takes up as means of distinguishing between features that he takes to be essential to sculpture as opposed to painting. These interpretative problems are further complicated by Hemsterhuis' tendency to move back and forth between considerations that bear on the creation of works of art and those that bear on the viewer's apprehension or appreciation of the finished work. Whereas his account of artistic creativity offers little more than a conservative restatement of well-worn and, to my mind, highly implausible ideas, his account of the different kinds of engagement that can be sustained by works of sculpture and painting connects productively with his core thesis, bringing to light not only its strengths but also its weaknesses.

Although Hemsterhuis uses the term optimum to characterise the unusual 'combination' that he identifies with beauty, he acknowledges that there are at least two ways in which this can be realised. He expresses this by observing that the artist can achieve beauty in his work by following 'two different paths': 
through the fineness and fluency of the contour he can give me in a second, for example, the idea of beauty, but in a state of rest, as in the Medici Venus or in your Galtea; but if with a contour equally fine and graceful, he were to represent an Andromeda with her fears and hopes visible in all her limbs, he would offer me in the same second, not only the idea of beauty, but also the idea of the peril of Andromeda; which would arouse, not only my admiration, but also my pity. [L: 39]

As Frits Scholten has shown, the Galatea to which Hemsterhuis refers is most likely an ivory carving by Francis van Bossuit (1635-1692) that was in de Smeth's collection. This sculpture is now lost but it is known from a pair of engravings (fig. 3), each showing a different view, in the Beeld-snyders Kunstkabinet, published in $1727 .{ }^{34}$ Scholten notes that 'The flowing outlines and the self-contained composition of the nude woman and her dolphin are a perfect illustration of Hemsterhuis' optimum of the tranquil observation of nature'. ${ }^{35}$ However, Hemsterhuis acknowledges that there is a necessary trade-off between rapidity of apprehension - facilitated through a continuous and flowing contour that allows the parts to be readily conjoined in a unified whole - and the quantity and vividness of the ideas that the artist is able to communicate through the work. The depiction of figures in action as opposed to rest, the expression of intense states of emotion, and the corresponding emotional engagement of the viewer, are all valuable in themselves, but they need to be weighed against the inevitable diminution of the 'flowing quality' of the contour, which 'makes it so easy to trace with our eyes' (qui le rend si facile à parcourir par nos yeux) [L: 3940]. Hemsterhuis develops this argument by contrasting a sculptural group representing Hercules and Antaeus, which he mistakenly attributes to Michelangelo, with Giambologna's celebrated Rape of the Sabines. ${ }^{36}$ Whereas Michelangelo is supposed to have achieved the optimum by 'augmenting the maximum quantity of ideas', representing both the 'action' of Hercules and the 'suffering' of Antaeus, Giambologna 'instead sought this optimum by reducing the minimum amount of time through the fineness of his contours' [L: 40]. Hemsterhuis does not yet place any normative value on one or other of these 
approaches: they are presented as equally legitimate alternatives, which can be more or less successfully realised.

Just as there can be a 'contradiction in the contour', a failure to demarcate the contour lines of different objects with sufficient clarity, so there can a 'contradiction in expression', an inconsistency in the affective content or emotional register of a sculpture [L: 41]. The first is illustrated by another of Hemsterhuis' drawings (fig. 4), this time made after an existing engraving, in which the ambiguous contour lines make it difficult to individuate figures and objects, thereby impeding our ability 'to grasp the idea of the whole' [L: 41]. The second is illustrated through reference to two well-known statues from antiquity. Here we are asked to imagine how the optimum that has been achieved in these works might be lost, if, for example, the repose of the Hercules Farnese were disrupted by an excessively tense muscle or the sufferings of Laocoön were counteracted by a limb or a facial feature expressing elation. In this context, Hemsterhuis also makes reference to the other ivory by Bossuit that was owned by de Smeth, a statue of Mars (fig. 5), which is now in the collection of the Rijksmuseum. Scholten observes that for Hemsterhuis, 'the ivory did indeed possess great suppleness of outline and repose, and hence considerable tranquil beauty but this was to an extent upset by the active arm on the point of drawing a sword, which - like the theoretical tensed muscle of the Hercules Farnese - ran counter to the optimum.'37

The underlying distinction between two different ways of realising the desired optimum, one weighted toward the minimum of time and the other toward the maximum of ideas, flows directly from Hemsterhuis' formulation of his basic principle. The resulting contrast, albeit highly generalised, does seem to capture a genuine pull between conflicting requirements that needs to resolved in particular cases. Nonetheless, this first step in the application of the principle brings out an underlying ambiguity or equivocation in Hemsterhuis' use of the term 'idea' that needs to be addressed before we go any further. On the one hand, he uses it in a narrow or restricted sense to refer to the visually apprehended parts of an object that have to be connected with one another in order to identify 
something as a unified whole or totality. This is how he uses the term when he analyses the temporally extended act through which the mind makes the 'connection' or liaison between a plurality of 'elementary points'. In his analysis of the two vases, he is able to distinguish 'intensity' from 'duration' by assuming that both possess the same quantity of ideas, and here he is evidently referring to their manifest visual properties. However, he also operates with a more substantial and cognitively rich conception of what constitutes an 'idea', using it to describe a range of different kinds of representational content. This is particularly apparent in the application of his basic principle to other art forms, such as poetry, for here the ideas to which he refers are instanced by vivid images, metaphors and other kinds of contentful thought.

It is clear that both senses of the term 'idea' are doing important work in Hemsterhuis' account of the different ways in which the optimum balance can be achieved in sculpture. Whereas his analysis of the way in which the flowing quality of the contour contributes to minimising the amount of time required can be understood in terms of our ability to connect a plurality of 'elementary points', and thus as narrowly perceptual, the depiction of figures in action or in heightened emotional states involves a semantically rich presentation of events and mental states whose apprehension goes beyond the mere connection of a work's visible parts. It is the inclusion of significant representational content that permits the maximisation of the number of ideas. However, the viewer's ability to identify what are standardly termed 'representational properties', as opposed to manifest visible properties, cannot be explained solely through the laws of optics or the functioning of the human visual processing system, since the identification of such properties requires the exercise of advanced cognitive capacities. $^{38}$

These two meanings of the term 'idea' are distinct, and Hemsterhuis does not do enough to distinguish when he is moving from the one to the other. However, this recognition, on its own, does not suffice to undermine his position. It can plausibly be argued that just as the mind takes time to grasp the liaison between a plurality of visible 'elementary points', so it also takes time to process or 
synthesise the presentation of cognitively rich ideas. Here, too, a multiplicity of constituent features needs to be brought together as a complex unity though an 'act of the mind'. In both cases, there is a trade off between the density (or complexity) of what is presented to the viewer and the rapidity (or facility) with which this can be apprehended. Indeed, the restriction to manifest visible properties alone would result in a rather limited formalism and fail to do justice to the distinctive kinds of interest we take in works of art. On this interpretation, it is a virtue of Hemsterhuis' account that it encompasses both perceptual and representational properties, even if the relation between the two is inadequately clarified.

What seems to have most troubled eighteenth-century readers is the absence in Hemsterhuis' definition of beauty of anything corresponding to the traditional concept of proportion. The anonymous author of a highly critical notice of his Oeuvres philosophiques in The Monthly Review put this point in the following terms:

It is allowed that we call that object beautiful, whether it be of nature or of art, of which we easily attain a full and comprehensive view; our sense of its beauty does not depend on the mere number of ideas which are combined in our conception of the whole, but on the facility with which these ideas coalesce; that is, on their relation to each other, and their coincidence with our preconceived notions of fitness and proportion. A mere collection of various ideas which have no other relation to each other, than that of the succession in which they are forced on the mind, will no more produce the sense of beauty, than an assemblage of heterogeneous parts, which have no other connexion than that of juxtaposition, will constitute the beautiful. ${ }^{39}$

What gives this argument its bite is the suggestion that Hemsterhuis has failed to achieve one of his primary goals. His theory is intended to explain the difference between the haphazard conjunction of heterogeneous features that characterises the child's drawing of a horse and the kind of order that allows a successful work 
of art to be rapidly apprehended even where its constituent parts possess a high degree of internal complexity. In his essay-length review of the Lettre sur la sculpture, Garve also contends that Hemsterhuis' reduction of the concept of beauty to just two factors fails to acknowledge the role of proportion or what he characterises more generally as the 'relationship' (Verhältnis) that pertains between the parts:

Neither for the eye nor for the mind is it solely the quantity of ideas and the speed with which they are apprehended that determines their effect, rather much also depends on their quality and their relationship to each other ... it is in these features that everything we term proportion is to be found, and it is indisputably on this that most our pleasure depends. ${ }^{40}$

Garve goes into some detail about the viewer's ability to appreciate the relative length and arrangement of lines and angles, both in relation to each other and to the central axis, but it is difficult to see that this adds much to Hemsterhuis' account. Instead of moving directly to the conclusion that the omission of the concept of proportion constitutes an explanatory deficit, it makes more sense to assume that Hemsterhuis sought to dispense with this as an unnecessary component. It is not merely that there is no shortage of guidance on this topic already available in academic teachings. Rather, the effectiveness of Hemsterhuis' definition of beauty derives from its very economy: the isolation of two quantitatively measurable factors that stand in an inversely proportional relationship to one another.

\section{Pictorial and sculptural viewing}

With these reservations and clarifications in mind, I now want to turn to the second stage in Hemsterhuis' application of his basic principle: its deployment as a means of distinguishing between sculpture 'in the round' (de ronde-basse), as opposed to sculpture in 'low relief' (bas-relief), and the two-dimensional art of painting [L: 52]. It is not until the third and concluding section of the letter that he directly addresses this topic, declaring that he now intends to consider 
sculpture in more detail, in order to analyse in what respect it differs from the other arts: what the limits are that its nature seems to prescribe for it (quelle sont les bornes que sa nature paraît lui prescrire), and what choice it demands in the subjects that it must treat' [L: 52]. The central move here is to take up the distinction he has already drawn between two different 'paths' to beauty in sculptural practice and to show that this can informatively be carried over to sculpture and painting. Hemsterhuis begins by noting that although sculpture 'represents perfectly that which it wants to represent, in depicting the whole contour and all the solidity of the subject' [L: 53], it is limited by its nature to the representation of a single figure or just a few figures. Curiously, he seeks the explanation for this in the hardness of the materials that are used, contrasting the malleability of paint with the labour required to work with marble, metal or other 'precious material'. His key claim, however, is that once we accept that sculpture is essentially an art of 'unity or simplicity', it follows directly that:

it should seek to perfect the minimum of time that is required in order arrive at an idea of the object through the fluency and excellence of its contours rather than increasing the maximum of the quantity of ideas through a perfect expression of actions and of passions. [L: 53]

By contrast, the art of painting, which can 'contain twenty rich compositions, which together will form a great general composition' [L: 53], allows for complex, multi-figure subjects, and hence for the communication of a greater number and diversity of actions and emotional states. In short, the first means of achieving the desired optimum, which prioritises the minimum of time, is identified with sculpture, and the second, which prioritises the maximum of ideas, is identified with painting. The key difference is that the distinction is now structured normatively. Although it is open to the sculptor to follow both paths as is evident from Hemsterhuis' earlier discussion - the claim that sculpture is by nature an art of 'unity or simplicity' takes on an evaluative dimension: individual works can be said to succeed or fail to the extent that they conform to or deviate from the requirement of minimising the amount of the time required to apprehend the individual parts as a totality. 
We are so well-prepared for this conclusion by the time that it arrives, that it inevitably strikes the reader as rather underwhelming. This effect is reinforced by Hemsterhuis' presentation of his views as directly confirming many of the standard tropes about the 'purpose' and 'excellence' of sculpture that are familiar from the writings of Winckelmann and others who promoted an idealised conception of the sculpture of antiquity as a model for the renewal of the arts. One would have to work very hard indeed to identify any new insights in Hemsterhuis' list of the conditions, detailed in the closing pages, that the sculptor has to satisfy in order to achieve 'the greatest perfection in his art' [L: 54]. I have sought to show, however, that we need to be attentive to the ways in which Hemsterhuis both conforms to and departs from the central tenets of classicist aesthetics. Particularly helpful for our purposes here is the highly compressed analysis of the Lettre sur la sculpture by Hemsterhuis' contemporary, Moses Mendelssohn, which was written as a means of working out his own ideas rather than as a free-standing review intended for publication. Despite its brevity, Mendelssohn's discussion merits close consideration, both for what it reveals about the Lettre and for its contribution to the broader debate about the relation between the different arts, a debate which Mendelssohn had helped to initiate through his own writings. ${ }^{41}$

\section{Mendelssohn's algebraic reformulation}

In his short 'review' of the Lettre sur la sculpture, Mendelssohn distinguishes those features of Hemsterhuis' position that he finds persuasive from those with which he disagrees or that he is unable to accept without further emendation. He accepts as correct Hemsterhuis' observation that 'in the case of sculpture it is unity (the minimum of time) that prevails whereas for painting it is multiplicity'. He also endorses his conclusion that 'For this reason, sculpture is less concerned with action, has greater repose, and also less composition'. ${ }^{42}$ However, he finds his proposal that the explanation for this is to be found in the nature of the materials used by sculpture unconvincing. He therefore provides an alternative 
way of reconstructing Hemsterhuis' position that focuses instead on the different kinds of 'temporality' that are proper to sculptural and pictorial viewing. Here he clearly has in mind Lessing's argument in the Laocoön that whereas poetry, as a narrative art, is able to represent a continuous sequence of events, painting and sculpture, as visual arts, are limited to the representation of a single moment in time. However, in opposition to Lessing he seeks to show that there are also important differences between painting and sculpture, differences that can be elucidated through reference to Hemsterhuis' principle that beauty consists in a maximum of ideas in a minimum of time. Mendelssohn sets out his ideas as follows:

A painting is made to be seen from a single point in space. Even when what is represented is transitory, it therefore depicts only a moment in time; and for the viewer this moment of time repeats itself over and over again when he looks at the painting. This is something that belongs to the nature of painting. It can only represent what is transitory by selecting the most appropriate moment (den glüklichsten Zeitpunkt).

By contrast, sculpture is made to be seen from more than one point of view. For this reason, it should represent states of affairs that last for several moments without constant alteration. When I move to another position to view the sculpture, I expect - in accordance with the nature of what is transitory - that it will have changed: unity is thereby harmed. However, I can view beauty in a state of rest from all sides without expecting it to have undergone any alteration.

For this reason, sculpture is less able to accommodate actions and groups of figures. The sculptor cannot require that the viewer constantly hold in mind an earlier moment of time, since the work is made to be seen over a plurality of moments of time. ${ }^{43}$

In contrast to the rather abstract way in which Hemsterhuis approaches the relation between sculptural and pictorial viewing, Mendelssohn asks us to 
consider what is actually involved in each case. His central argument, as I understand it, is that in moving around a sculpture in order to view it from different positions we are made more insistently aware of the difference between what we might call the 'internal' time of the sculpture - the time in which its depicted content is represented as taking place - and the temporal framework that we inhabit as viewers external to the work. It is, of course, true that viewing a painting is also a durational experience that unfolds in time, and that here too a gap or distance opens up between the two different temporalities. However, the need to hold in mind a plurality of perspectives as we alter our position in relation to a work of sculpture in the round imposes additional demands. Here the representation of 'beauty in a state of rest' is a positive advantage since it allows the viewer to bring together or synthesise a multiplicity of viewpoints that are spatially as well as temporally discrete. Whereas groups of figures engaged in complex interactions can readily be grasped in a painting - since paintings are designed to be viewed exclusively from a frontal standpoint - this would overtax the viewer of a sculpture, who must carry out the more demanding task of 'unifying' the individual parts of the work as seen from different positions over an extended period of time.

These observations can be read as an elucidation or perhaps even a further extension of Hemsterhuis' application of his core thesis, but they are underpinned by some telling criticisms that Mendelssohn sets out in the dense opening paragraph of his review, which I here cite in full:

The author is Hemsterhuis le fils. Beauty, he correctly observes, consists in a maximum of ideas in a minimum of time. However, what is meant by the maximum of ideas needs to be properly explained. For this can be understood not only in terms of extension (the quantity of concepts), but also in terms of intension (their clarity, effectiveness, and so forth). The maximum of ideas corresponds to multiplicity, and the minimum of time to unity. This minimum is not merely a matter of the time involved, but also the degree of effort required. However, it is not correct to say that beauty corresponds directly to the quantity of ideas and indirectly to the time 
required. For if it is the case that $\mathrm{q}: \mathrm{Q}=\mathrm{T}: \mathrm{t}$, beauty can nonetheless be qt $>$ or < as QT. More precisely: beauty corresponds to the quantity of concepts in a given period of time. ${ }^{44}$

Mendelssohn's algebraic formulae do not permit of ready comprehension and he does not offer any further clarification of their meaning outside of this single paragraph. We cannot excluded the possibility that he deployed his own private code or shorthand, to which we no longer have the key. Nonetheless, it is worth persevering in the attempt to make sense of his analysis, since this difficult passage contains some important insights. It is plausible to assume that the letter ' $q$ ' stands for 'quantity' (Latin: quantus), while the letter ' $t$ ' stands for 'time' (Latin: tempo). If we introduce the letter ' $b$ ' for beauty, we can use Mendelssohn's notation to set out Hemsterhuis' basic principle as follows:

$$
\begin{aligned}
& b=\text { beauty } \\
& q=\text { quantity (quantas) } \\
& t=\text { time (tempo) }
\end{aligned}
$$

Beauty $(b)$ consists in the maximum number of ideas $(q)$ in the minimum amount of time $(t)$ or $b=q: t$.

This principle contains two generic desiderata:

1. $q$ should be as large as possible (maximum);

2. $t$ should be as small as possible (minimum).

Next, we can specify the rules that govern the application of this principle to the individual art forms of sculpture and painting by identifying two further medium-specific desiderata:

3. in the art of sculpture, desideratum 1 takes precedence over desideratum 2; 
4. in the art of painting, desideratum 2 takes precedence over desideratum 1.

By using Mendelssohn's notation to set out Hemsterhuis' argument in a more clearly structured way, we are now in a position to identify the criticisms Mendelssohn puts forward and to offer a provisional interpretation of his rather cryptic algebraic formulae. Mendelssohn makes two closely related objections to Hemsterhuis' basic principle. First, he argues that the 'maximum of ideas' should not be understood in merely quantitative terms, for what matters in our appreciation of works of art is not simply the number of ideas expressed but also the way in which they are presented, which he glosses as 'their clarity, effectiveness and so forth'. To articulate this objection, he uses the distinction, familiar from semantics, between the 'extension' of a term (the set of things to which the term is properly applied) and its 'intension' (the set of essential properties that determine the applicability of the term itself.) ${ }^{45}$ However, in this context, he is best understood as drawing a distinction between the quantity of ideas presented through a work of art and what can be termed their 'quality', that is to say, their force, vividness, clarity, or other features that cannot be enumerated in merely quantitative terms. This would allows us to determine his use of the lower and upper case letter ' $q$ ' as:

$$
\begin{aligned}
& q=\text { quantity of ideas } \\
& Q=\text { quality of ideas }
\end{aligned}
$$

If we now examine Mendelssohn's second objection, we can see that it has a similar structure. He observes that the reduction of time to a minimum should not be understood in merely quantitative terms, that is to say, exclusively in terms of the number of measurable units of time that elapse, but also in terms of the degree of effort involved on the part of the viewer. Here Mendelssohn picks up on Hemsterhuis' own observation that successful works of art are 'great totalities (grands touts), whose parts are so artistically composed that the mind can connect them together in an instant and without effort (que l'âme en peut 
faire la liaison dans le moment et sans peine)' [L: 37]. By giving greater weight to Hemsterhuis' remarks about the facility with which the viewer is able to apprehend a plurality of parts as a unified whole, Mendelssohn distinguishes between the quantity of time involved and its qualitative character, understood as the degree of effort exerted. If this interpretation is correct, then we can determine his use of the lower and upper case letter ' $t$ ' as follows:

$$
\begin{aligned}
& \mathrm{t}=\text { time (duration) } \\
& \mathrm{T}=\text { effort over time }
\end{aligned}
$$

If we now combine these two objections, we can see that the upshot of Mendelssohn's emendations is to replace Hemsterhuis' two-fold distinction with a four-fold distinction that takes into account qualitative as well as quantitative factors. This provides a plausible way of making sense of the claim that he expresses using his algebraic notation:

Beauty (b) does not consist in a relation between two factors (q; t) but in a relation between four factors (q; Q; t; T);

Since qt can be greater or lesser as QT, $\mathrm{b}=\mathrm{qt}>$ or $<$ as QT.

In other words, beauty does not consist simply in a maximum of ideas in a minimum of time, but also in the clarity and effectiveness with which these ideas are expressed and the degree of effort involved in their apprehension. Moreover, since these qualitative and quantitative factors can vary independently of each other, not only the maximum of ideas and the minimum of time, but also the realisation of an optimum balance between them can be achieved in different ways.

An alternative way of interpreting Mendelssohn's notation has been suggested to me by the philosopher of mathematics, Christian Wenzel. ${ }^{46}$ Wenzel's proposal is that after having observed that the idea of a maximum and minimum can be further refined in terms of extension and intension, Mendelssohn goes on to 
pursue a second, independent line of criticism. On this interpretation, Mendelssohn uses capital letters to represent the standard view and lower case letters to represent the position he advocates. The standard view, as Mendelssohn expresses it, is 'that beauty corresponds directly to the quantity of ideas and indirectly to the time required.' Mendelssohn's counter-proposal, introduced by the phrase 'More precisely' (Richtiger), is that the quantity of ideas can vary at different moments of time. The viewer might apprehend 5 ideas at time $t_{1}, 7$ ideas at $t_{2}, 2$ ideas at $t_{3}$, and so on. Wenzel notes that the recognition that q can vary with $t$ is of particular relevance to sculptural viewing, since as the viewer moves around the sculpture she is likely to apprehend different quantities and kinds of ideas at different times. There is much to be said for this interpretation, which is genuinely illuminating. The density of Mendelssohn's argument and the obscurity of his system of notation makes it difficult to decide which interpretation is correct. I therefore present them here without advocating one or the other.

On both readings Mendelssohn succeeds in identifying the shortcomings of Hemsterhuis' narrowly quantitative approach while, at the same time, helping us to understand how his ideas about the durational character of aesthetic experience might be productively developed in relation to specific art forms. In the final part of this paper, I want to focus more closely on Hemsterhuis' highly ambivalent treatment of the concept of duration, which he recognises both as essential to our apprehension of works of art and as a defining weakness or failing of human nature that we constantly strive to overcome.

Time as a negative factor

Somewhat surprisingly, given the centrality accorded to duration in Hemsterhuis' account of pictorial and sculptural viewing, the desideratum that time be reduced to a minimum does not merely articulate the need for clarity and effectiveness in the communication of complex content so that it can be readily apprehended by the viewer. It is also expresses a deep-lying hostility or 
aversion towards the temporal dimension of experience. In the concluding remarks to the first, 'metaphysical section' of the Lettre, Hemsterhuis observes that 'it seems incontestable that there is something in our mind that loathes any relationship with what we call succession or duration' (il paraît incontestable qu'il y a dans notre âme quelque chose qui répugne à tout rapport avec ce que nous appelons succession ou durée)' [L: 43]. ${ }^{47}$ This observation, which appears so out of keeping with the rest of the Lettre, forms the starting point for Hemsterhuis' next work, the Lettre sur les désirs, which he published the following year in 1770 as a continuation and further development of his earlier views. The way in which Hemsterhuis summarises the central argument of the Lettre sur la sculpture is informative, since it reveals a subtle shift of emphasis:

I believe that in my previous letter I proved that the mind always seeks the greatest number of ideas in the shortest amount of time and that it is prevented from fully achieving this by its necessary reliance on the senses, which depend on the succession of time and the relation of parts. ${ }^{48}$

This negative appraisal of the constraints imposed by the apprehension of external objects through the senses is justified through reference to the kind of knowledge that would be available to us were we capable of direct or immediate intuition. Hemsterhuis contends that 'If the mind could be affected by an object without the medium of the sense organs, the time required to apprehend an idea would be reduced to exactly zero.' By the same token, 'If the object was constituted in such a way that the mind could grasp the complete totality of the essence of the object, the number of ideas would be absolutely infinite.' ${ }^{49}$ Much of the Lettre sur les désirs is given over to an account of the various ways in which human beings seek to overcome their finitude in order to achieve union with the object of desire, whether it be a work of art, another person, or the divine, without ever being able fully to achieve this goal. It is this aspect of Hemsterhuis' philosophy that made his ideas so attractive during the ascendency of German Romanticism. However, it is telling that from this point on in his published works Hemsterhuis ceased to pay serious attention to the distinctive 
kinds of engagement that can be sustained by works of art: the Lettre sur la sculpture was to remain his sole contribution to aesthetics.

Some of the more perplexing claims that Hemsterhuis puts forward in the Lettre sur la sculpture can be understood as deriving from his commitment to the idea that our apprehension of works of art necessarily falls short of direct or immediate intuition. This is particularly apparent in his discussion of artistic creation, where the artist is supposed to possess the ability to grasp the idea of an object 'immediately in the form of a whole and without the succession of parts', but as having to 'decompose' (diviser) the idea in order to represent it in a work of sculpture, painting or poetry, with the result that the now separated parts 'must succeed one another in order to represent the whole' [L: 36]. In other words, there is an inevitable loss of unity that takes place when the original idea, which is 'conceived in the mind', is embodied in a work of art. ${ }^{50}$ Hemsterhuis' conclusion that 'It is easy to see that this long operation will necessarily much reduce the splendour of the idea' [L: 36-7] bears comparison with the reductio of this conception that Lessing articulates through the character of the painter, Conti, in his play Emilia Galotti: 'Alas! that we cannot paint directly with our eyes! On the long journey from the eye through the arm to the brush, how much is lost!'. 51

Similar problems are operative in Hemsterhuis' account of the evaluative transformation - or rather inversion - that takes place if we spend an extended period of time looking at an object that we initially judge to be beautiful. He introduces this argument as a means of confirming his contention that the beautiful does not have any reality in itself', but it is unclear whether he is simply thinking through the consequences of his views or describing another 'aesthetic experiment' that he has actually carried out. His proposal is that, if viewed for a sufficiently long period of time, a group of vases that possess 'all the principles of beauty', would cease to give us pleasure and eventually awaken a sense of 'disgust' (dégoût), whereas a group of vases that we initially found ugly would come to seem beautiful [L: 42]. In order to explain this phenomenon, he suggests that, in the first case, the eye starts to discover 'nooks and crannies', which it had 
initially glided over, whereas in the latter case the eye develops practice in grasping the contours so that it can now apprehend the whole with the requisite rapidity. What is missing here, of course, is any sense of the way in which sustained looking can deepen and enrich our experience of works of art or the pleasure that is derived from our tendency to dwell on those objects that reward our attention. ${ }^{52}$

Hemsterhuis maintains that he has succeeded in identifying a 'singular quality of the mind' [L: 43], and much of the Lettre sur les désirs is given over to elucidating the reasons for the 'disgust' we feel towards anything that we contemplate for an extended period of time. This emphasis on the limitations of human finitude plays an important role in his larger metaphysics. However, in the context of his theory of art, the supposition that we driven by an unfulfilled yearning for complete union with the object of desire, unmediated by the senses, leads to a corresponding detachment from the sustaining conditions under which works of art are actually viewed. On the interpretation I have put forward here, the real achievement of the Lettre sur la sculpture lies Hemsterhuis' elucidation of the temporally extended empirical and psychological processes that are involved in the apprehension of complex kinds of unity. By contrast, the idea of direct or immediate intuition - with its corresponding denigration of sensory knowledge remains indebted to the neo-Platonic strand of classicist art theory, from which Hemsterhuis otherwise seeks to distance himself. We therefore need to recognise that the Lettre sur la sculpture is characterised by a tension between two conflicting approaches and that his appeal to the idea of an immediately apprehended whole is incompatible with other aspects of his account. That the Platonic dimension of Hemsterhuis' thinking ultimately prevailed makes it all the more remarkable that in this short and densely-argued text he was able to articulate an alternative point of view that gives precedence to the temporal and spatial conditions of perception, that is to say, to the actual processes through which we apprehend the complex unity that we perceive in a work of art. 
${ }^{1}$ Goethe's participation in the Prussian campaign is vividly recounted in N. Boyle, Goethe: The Poet and the Age. Volume II. Revolution and Renunciation (17901803), Oxford, Clarendon Press, 2000, pp. 116-146.

2 J. W. Goethe, Campagne in Frankreich, 1792 (first published in 1822), in Goethes Werke, Weimarer Ausgabe, Vol. 33, Weimar, H. Böhlau, 1898, p. 234: 'Das Schöne und das an demselben Erfreuliche sei, so sprach er sich aus, wenn wir die größte Menge von Vorstellungen in einem Moment bequem erblicken und fassen; ich aber mußte sagen: das Schöne sei, wenn wir das gesetzmäßig Lebendige in seiner größten Tätigkeit und Vollkommenheit schauen, wodurch wir, zur Reproduktion gereizt, uns gleichfalls lebendig und in höchste Tätigkeit versetzt fühlen.'

${ }^{3}$ See, H. Moenkemeyer, François Hemsterhuis, Boston, Twayne, 1975, pp. 9ff. This remains the fullest account of Hemsterhuis' life and work in English.

${ }^{4}$ As Emmanuelle Baillon perceptively observes, 'the forms that he employed for his writings reveal the essential presence of the interlocutor at the heart of his work: first of all, the letter, explicitly addressed to a correspondent, in response to a certain question or request; and subsequently the dialogue form.' See 'Préface', François Hemsterhuis, Lettre sur la sculpture, ed. E. Baillon, Paris, énsba, 1991, p. 6.

${ }^{5}$ J. G. Herder, Plastik: Einige Warhnehmungen über Form und Gestalt aus Pygmalions bildendem Traume, Riga, Hartknoch, 1778. A substantial draft consisting of the first three chapters was completed in 1770 and then put to one side, so the original formulation of Herder's ideas is closer to the Lettre sur la sculpture than the publication date of 1778 might suggest. For an English translation, with an introduction and explanatory notes, see Sculpture: Some Observations on Shape and Form from Pygmalion's Creative Dream, ed. and transl. J. Gaiger, Chicago and London, The University of Chicago Press, 2002. An insightful comparison of Hemsterhuis' and Herder's views on sculpture is provided in A. Potts, The Sculptural Imagination: Figurative, Modernist, Minimalist, New Haven and London, Yale University Press, 2000, pp. 28-37. For Herder's unsuccessful attempt to have the Lettre sur la sculpture translated into 
German, see R. Norton, Herder's Aesthetics and the European Enlightenment, Ithaca and London, Cornell University Press, 1991, p. 223.

${ }^{6}$ J. G. Herder, 'Vorerinnerung des Uebersetzers', Der Teutsche Merkur, November 1781, p. 98; reprinted in J. G. Herder, Sämmtliche Werke, ed. B. Suphan, Vol. XV, Berlin, Weidmannsche Buchhandlung, 1888, pp. 55-56: 'seines Reichtums an Ideen, seiner Schönheit und Seltenheit'. Herder's essay is titled 'Liebe und Selbstheit: ein Nachtrag zum Briefe Herrn Hemsterhuis' (Love and Selfhood: A Supplement to the Letter of Herr Hemsterhuis).

7 Dennis Diderot, 'Observations sur Hemsterhuis', Oeuvres. 1: Philosophie, ed. L. Versini, Paris, Robert Lafont, 1994, pp. 694-770. Diderot's commentary was not discovered until 1960. See, François Hemsterhuis, Lettre sur l'homme et ses rapport avec le commentaire inédit de Diderot, texte établi, présenté et annoté par Georges May, New Haven, Yale University Press/ Paris, PUF, 1964.

${ }^{8}$ François Hemsterhuis, Oeuvres philosophiques, ed. H. J. Jansen, 2 vols., Paris, 1792.

${ }^{9}$ Garve's review appeared in the Neue Bibliothek der schönen Wissenschaften und der freyen Künsten, 11(2), 1771, pp. 269-39. Several sections of the review were translated into French by Jansen and included as annotations in his edition of the Oeuvre philosophiques, a practice that has been retained in many subsequent editions. Mendelssohn's critical discussion of the text, 'Zu Hemsterhuy's Lettre sur la sculpture', dated March 1776, was included in his so-called Kollektaneenbücher, in which he recorded his own notes and thoughts as well as excerpts from his reading. The text is reprinted in Moses Mendelssohn, Gesammelte Schriften: Jubiläumsausgabe, Vol. 3(1), Schriften zur Philosophie und Ästhetik, ed. F. Bamberger and L. Strauss, Berlin, Friedrich Frommann, 1972, pp. 273-4. Gotthold Ephraim Lessing's Laokoon, oder über die Grenzen der Malerei und Poesie was published in 1766, and is thus broadly contemporaneous with the Lettre sur la sculpture, though the first drafts, which Mendelssohn had seen and discussed, go back to 1763. For the text in English translation, see G. E. Lessing, Laocoön: An Essay on the Limits of Poetry and Painting, transl. E. A. McCormick, Baltimore and London, The Johns Hopkins University Press, 1984. 
10 H. Moenkemeyer, 'François Hemsterhuis: Admirers, Critics, Scholars', Deutsche Vierteljahrschrift für Literaturwissenschaft und Geistesgeschichte, 51(3), 1977, pp. 502-524 (this citation, p. 505). See, too, K. Hammacher, 'Hemsterhuis und seine Rezeption in der deutschen Philosophie und Literatur des ausgehenden achtzehnten Jahrhunderts', in M. F. Fresco, L. Geeraedts and K. Hammacher, eds., Franz Hemsterhuis (1721-1790). Quellen, Philosophie und Rezeption, Münster and Hamburg, LIT, 1995, pp. 405-32.

11 See, for example, the writings by Novalis gathered together as his 'Hemsterhuis-Studien' in Novalis Schriften, ed. R. Samuel, H-J. Mähl, and G. Schulz, Band 2: Das Philosophische Werke I, Stuttgart, Kohlhammer, 1965, pp. 360-78.

${ }^{12}$ A. W. Schlegel, Vorlesungen über dramatische Kunst und Literatur, Heidelberg, Mohr und Zimmer, 1809-11. The relevant section of the lectures in English translation is reprinted in C. Harrison, P. Wood and J. Gaiger, eds., Art in Theory: 1648-1815, Cambridge Mass., Blackwell, 2000, pp. 941-8.

13 Moenkemeyer, François Hemsterhuis, p. 43.

14 See Jacob van Sluis, 'Introduction', in François Hemsterhuis, Oeuvres philosophiques, Édition critique, ed., J. van Sluis, Leiden and Boston: Brill, 2015, p. 19.

15 Hemsterhuis, Oeuvres philosophiques, ed., van Sluis, as at note 14.

16 François Hemsterhuis, Lettre sur la sculpture, ed. E. Baillon, as at note 4.

17 Frans Hemsterhuis, Lettera sulla Scultura, translated by I. Crispini and D. Scalabrino, edited by E. Matasi, with an 'Afterword' by M. Cometa, Palermo, Aeshetica edizoni, 1994, and Frans Hemsterhuis, Escritos sobre éstetica, translated with an introduction and notes by M. P. Cornejo, Universitat de València, 1996.

${ }^{18}$ A short excerpt from the Lettre sur la sculpture, translated into English by Jonathan Murphy, is included in Harrison, Wood and Gaiger, Art in Theory: 16481815, pp. 639-40.

${ }^{19}$ For an examination of the apparent conflict between these two way of approaching historical texts in relation to the work of other eighteenth- and nineteenth-century thinkers, see for example, J. Gaiger, 'Hegel's Contested Legacy: Rethinking the Relation Between Art History and Philosophy', The Art 
Bulletin, 93(2), June 2011, pp. 178-194, and 'The Contemporaneity of Lessing's Aesthetics', in Lessing and the German Enlightenment, ed. R. Robertson, SVEC, Voltaire Foundation, 2013, pp. 97-117.

20 The Lettre sur une pierre antique is reprinted in Hemsterhuis, Oeuvres philosophiques, ed., van Sluis, pp. 84-7. On de Smeth, see F. Scholten, 'The Amsterdam Ivories of Francis van Bossuit: Reception and Transformation in the Eighteenth Century', in C. van Eck, ed., Idols and Museum Pieces: The Nature of Sculpture, its Historiography and Exhibition History 1640-1880, Berlin: de Gruyter, 2017, pp. 35-47.

${ }^{21}$ I include these drawings as figures in the relevant parts of this essay. All citations are from the translation by Peter Dent. I give references to the French edition by E. Baillon (as at note 4) using the abbreviation: $\mathrm{L}$.

22 For a critical discussion of the proposal that Hemsterhuis' formula is simply a restatement of the familiar idea of 'unity amidst multiplicity' or 'unity in diversity', whose antecedents can be traced back to ancient Greece in the writings of Xenophon and others, but which had become a commonplace of eighteenth-century art theory, see A. P. Dierick, 'Pre-Romantic Elements in the Aesthetic and Moral Theories of François Hemsterhuis (1721-1790)', Studies in Eighteenth-Century Culture, 26, 1987, pp. 247-271, esp. pp. 254-5, and P. C. Sonderen, 'Beauty and Desire: Frans Hemsterhuis' Aesthetic Experiments', British Journal for the History of Philosophy, 4(2), 1996, pp. 317-345, especially pp. 317-9. Both authors offer grounds for rejecting this proposal, Dierick through reference to Hemsterhuis' account of the role of sense perception and Sonderen through reference to Hutcheson's use of his own drawings to carry out 'aesthetic experiments' that allow him to test and demonstrate his conclusions.

${ }^{23}$ F. Hutcheson, An Inquiry Concerning Beauty, Order, Harmony, Design, edited with an introduction and notes by P. Kivy, The Hague, Martinus Nijhoff, 1973, p. 40.

${ }^{24}$ Hutcheson, An Inquiry, p. 80. As Paul Guyer observes, for Hutcheson, 'our pleasurable response to the perception of uniformity amid variety is not a cognition of that uniformity amid variety'. It is a causal response, triggered by the presence of the appropriate properties, understood in analogy to Locke's 
account of secondary qualities. See P. Guyer, A History of Modern Aesthetics. Vol. 1: The Eighteenth Century, Cambridge, Cambridge University Press, 2014, p. 105. 25 Hemsterhuis' formulation echoes familiar views put forward by figures such as Leon Battista Alberti, Giovan Pietro Bellori, André Félibien, and above all, Johan Joachim Winckelmann. The classic study of this tradition of thought is E. Panofsky, Idea: A Concept in Art Theory [1924], transl. J. S. Peake, Columbia, University of South Carolina Press, 1968. For a more recent assessment, see S. Halliwell, The Aesthetics of Mimesis: Ancient Texts and Modern Problems, Princeton, Princeton University Press, 2002, and A. Becq, Genèse de l'esthéthique française moderne: De la raison classique à l'imagination créatrice 1680-1814, Paris, Albin Michel, 1994.

${ }^{26}$ See J. J. Winckelmann, Reflections on the Imitation of Greek Works of Painting and Sculpture, complete German text with a new English translation by E. Heyer and R. C. Norton, La Salle, Illinois, Open Court, 1987, p. 17. Cf. Winckelmann's observation that 'In the masterpieces of Greek art, connoisseurs and imitators find not only nature at its most beautiful but also something beyond nature, namely certain ideal forms of its beauty, which, as an ancient interpreter of Plato teaches us, come from images created by the mind alone' (7). The 'ancient interpreter' to whom Winckelmann refers is most likely Proclus in his Commentary on the Timaeus.

27 Moenkenmeyer notes that although Winckelmann's Geschichte der Kunst des Altertums (The History of Art in Antiquity) was published in 1764, it was not translated into French until 1766 and that Hemsterhuis only had limited knowledge of German. See Moenkenmeyer, François Hemsterhuis, p. 32. Whether or not Hemsterhuis was able to consult this text, the central terms of his analysis are already to be found in Winckelmann's earlier writings.

${ }^{28}$ See, L. B. Alberti, On Painting [1435], transl. C. Grayson, London, Penguin, 2004. Alberti observes that 'we must investigate how it is that, with change of position, the properties inherent in a surface appear to be altered. These matters are related to the power of vision; for with a change of position surfaces will appear larger, or of a completely different outline from before, or diminished in colour; all of which we judge by sight' (pp. 39-40). It is noteworthy that Alberti, 
unlike Hemsterhuis, does not restrict his analysis to contour alone but is also concerned with changes in light and colour. For an analysis of this passage, see J. Gaiger, Aesthetics and Painting, London and New York: Continuum, 2008, pp. 357

${ }^{29}$ For a useful summary of the recent literature, see M. Carrasco, 'Visual Attention: The Past 25 Years', Vision Research, 51, 2011, pp. 1484-1525, and E. Kowler, 'Eye Movements: The Past 25 Years', Vision Research, 51, 2011, pp. 1457 1483.

${ }^{30}$ My discussion here draws in particular on R. Rosenberg and C. Klein, 'The Moving Eye of the Beholder: Eye Tracking and the Perception of Paintings', in J. P. Huston, M. Nadal, F. Mora, L. F. Agnati, and C. J. Cela-Conde, eds, Art, Aesthetics and the Brain, Oxford, Oxford University Press, 2015, pp. 79-108. I examine these issues in greater detail in my 'Pictorial Experience and the Perception of Rhythm', in The Philosophy of Rhythm: Aesthetics, Music, Poetics, ed. A. Hamilton and M. Paddison, Oxford: Oxford University Press, forthcoming 2018.

${ }^{31}$ Sonderen, 'Beauty and Desire', p. 324.

32 I have taken the term 'effects' from Hemsterhuis' original formulation of the claim that art should 'go beyond' nature at the start of the Lettre, which can now be read differently in light of the subsequent development of his argument. His observation that art surpasses nature by 'producing effects that she does not produce with ease, or which she would not know how to produce' [L: 31] already anticipates his contention that the optimum balance between density of ideas and rapidity of apprehension is only infrequently or contingently to be found in nature herself.

33 Garve also draws a distinction between the arguments Hemsterhuis puts forward in order to establish his core principle and the arguments he puts forward in order to demonstrate its 'application' (Anwendung). See Garve 'Review of Lettre sur la Sculpture', p. 297.

${ }^{34}$ See Scholten, 'The Amsterdam Ivories', pp. 40-41. Scholten establishes that the Galatea was one of a pair of ivories by Bossuit, originally identified as representing Venus and Mars, which De Smeth acquired in 1754.

35 Scholten, p. 41. 
${ }^{36}$ Is not clear what work Hemsterhuis has in mind here, as there is no record of a large scale sculpture of Hercules and Anteaus by Michelangelo. For a discussion of the possible reasons for this (mis)attribution, see van Sluis, p. 694.

37 Scholten, p. 42.

38 See, for example, S. Irwin, 'Artworks and Representational Properties', Dialogue, Vol. 43(4), 2004, pp. 627-644. For a sophisticated take on these issues, see P. Lamarque, Work \& Object: Explorations in the Metaphysics of Art, Oxford, Oxford University Press, 2010.

${ }^{39}$ Review of 'Oeuvres Philosophiques, \&c. i.e. The Philosophical Works of M. F. Hemsterhuis', The Monthly Review, for January 1793, London, Ralph Griffiths, pp. 531-8, this citation, p. 532. The reviewer provides a clear and succinct summary of Hemsterhuis' core thesis, but goes on to observe that 'this hypothesis, with its application, is, in our opinion, full as confused as any thing that we ever saw'.

40 Garve, 'Review of Lettre sur la Sculpture', p. 302: 'Uns dünkt, daß weder im Auge noch in der Seele, mit der Anzahl und mit der Geschwindigkeit der Vorstellungen alles gethan sey, sondern daß auch vieles auf die Beschaffenheit der Vorstellungen, and auf ihr Verhältniß ankomme ... und doch liegt darinnen alles was man Proportion nennt, worauf unstreitig ein großer Theil des Wolhlgefallens beruht.' The relevant passage in French translation is reprinted in van Sluis, p. 690.

${ }^{41}$ See, in particular, M. Mendelssohn, 'Betrachtungen über die Quellen und Verbindungen der schönen Künste und Wissenschaften', in Bibliothek der schönen Wissenschaften und der freyen Künste, 1(2), 1757, pp. 231-68. This essay is translated as 'On the Main Principles of the Arts and Sciences', in M. Mendelssohn, Philosophical Writings, ed. D. O. Dahlstrom, Cambridge, Cambridge University Press, 1997, pp. 169-191.

42 Mendelssohn, 'Zu Hemsterhuy's Lettre sur la sculpture', p. 273: 'die Bemerkung ist richtig, daß in der Bildhauerkunst mehr Einheit (Minimum der Zeit), in der Malerey mehr Mannigfaltigkeit herrschen müsse; daher in der Bildhauerkunst weniger Handlung, mehr Ruhe, auch weniger Composition Statt findet.' Mendelssohn goes on to note that 'Nicolai frequently raised this objection against Lessing's Laocoön' (Diese Bemerkung hat Nicolai sehr oft gegen Lessings 
Laokoon zu behaupten versucht). Here Mendelssohn is referring to the detailed criticisms of the early drafts of the Laocoön that both he and Christoph Friedrich Nicolai had exchanged with Lessing. These are reprinted in full in W. Barner, ed. Lessing Laokoon. Text und Kommentar. Werke 1766-1769, Frankfurt am Main, Deutscher Klassiker Verlag, 1990, pp. 217-50.

43 Mendelssohn, 'Zu Hemsterhuy's Lettre', pp. 273-4: 'Die Malerey ist bestimmt, aus einem einzigen Punkte des Raumes angesehen zu werden. Sie drückt daher auch von dem Transitorischen nur einen Augenblick der Zeit aus; und der Betrachter muß diesen Augenblick der Zeit immer wiederholen, wenn er das Gemälde lange ansieht. Diese Anforderung ist der Natur der Malerey gemäß; und sie kan daher das Transitorische gar wohl ausdrücken, wenn sie den glüklichsten Zeitpunkt wählt. / Die Bildhauerkunst hingegen ist bestimt, aus mehr als Einem Augpunkt betrachtet zu werden; daher drükt sie lieber den Zustand aus, der einige Augenblicke fortdauert und sich nicht sogleich verändert. Indem ich meinen Standort ändere, um die Bildsäule zu betrachten, erwarte ich, der Nature des Transitorischen gemäß, daß sich dieses auch unterdessen verändert haben werde; und Einerley beleidigt. Die Schönheit in Ruhe aber kan ich von allen Seiten betrachten, ohne Veränderungen zu erwarten. / Daher läßt sich weniger Handlung, auch weniger Gruppe in der Bildhauerey anbringen. Der Bildhauer kan nehmlich nicht die Anforderung voraussetzen, der Betrachter solle sich öfters in den Augenblick der Zeit zurückdenkent, weil sein Werk bestimt ist, in mehreren Augenblicken angesehen zu werden. - Das Bas-relief hat mehr Augenblicke als die Malerey, und weniger als die Bildhauerkunst. Daher kan die Vorstellung auf demselben mehr transitorisch seyn als in jener; aber doch weniger als in der Malerey.'

${ }^{44}$ Mendelssohn, 'Zu Hemsterhuy's Lettre', p. 273: 'Der Verfasser nennt sich Hemsterhuys le fils. - Die Schönheit, sagt er mit Recht, besteht in einem Maximo der Ideen, in einem Minimo der Zeit; nur is das Maximum der Ideen richtig zu erklähren. Es its nehmlich nicht nur extensive (die Menge der Begriffe), sondern auch intensive (die Klarheit, Wirksamkeit u.s.w.) zu verstehen. Das Maximum der Ideen entspricht der Mannigfaltigkeit, und das Minimum der Zeit der Einheit. Dieses Minimum gehet auch nicht nur auf die Zeit, sondern auch auf die Kraft der 
Anstrengung. Man kann aber nicht sagen, die Schönheit verhalte sich direkt wie die Quantität der Ideen, und indirekt wie die Zeit. Denn wenn auch $\mathrm{q}: \mathrm{Q}=\mathrm{T}: \mathrm{t}$; so kan doch die Schönheit qt > oder < als QT seyn. Richtiger: die Schönheit verhält sich wie die Quantität der Begriffe in einer gegebenen Zeit.'

${ }^{45}$ For this definition of the standard use of terms 'extension' and 'intension' in semantics, I have drawn on A. Conti, 'Walter Burley', The Stanford Encyclopedia of Philosophy (Summer 2016 Edition), Edward N. Zalta (ed.), URL = <https://plato.stanford.edu/archives/sum2016/entries/burley/>.

46 Wenzel is also an expert on eighteenth-century aesthetics, who has published extensively on Kant's philosophy. He kindly communicated his ideas through private conversation and correspondence when I turned to him for assistance with Mendelssohn's notation.

47 Garve found this remark particularly puzzling and devotes several pages of his review to trying to making sense of it. See, Garve, 'Review of Lettre sur la Sculpture', pp. 312-5.

${ }^{48}$ Hemsterhuis, Lettre sur les désirs, in van Sluis, p. 152: 'Je crois vois avoir prouvé dans ma précédente, que l'Ame cherche toujours le plus grand nombre d'idées possible dans le plus petit espace de temps possible, et que ce qui l'empêche de se contenter à cet égard, réside dans la nécessité où elle se trouve de se servir d'organes et de moyens, et d'agir par succession de temps et de parties.'

${ }^{49}$ Hemsterhuis, Lettre sur les désirs, p. 153: 'Si l'Ame pouvoit être affectée par un object sans le moyen des organes, le temps qu'il lui faudroit pour s'en faire l'idée seroit réduit exactement à rien. / Si l'objet étoit tel, que l'Ame pût être affectée par toute las totalité de l'essence de cet objet, le nombre des idées deviendroit absolument infini'.

50 This is the reason for Hemsterhuis' claim that 'it is the first sketches that most please the man of genius and the true connoisseur ... they maintain more of that divine vivacity of the idea first conceived' [L: 38].

${ }^{51}$ Lessing, Emilia Galotti, Act I, Scene iv: 'Ha! daß wir nicht unmittelbar mit den Augen malen! Auf dem langen Wege, aus dem Auge durch den Arm in den Pinsel, wie viel geht da verloren!' Conti goes on to observe that 'Raphael would still have 
been the greatest painter that ever lived even if he had unfortunately been born without hands' ('Raffael ... das größte malerische Genie gewesen wäre, wenn er unglücklicherweise ohne Hände wäre geboren worden'. See, G. E. Lessing, Emilia Galotti: Ein Trauerspiel, ed. G. Eversberg, Hollfeld, C. Bange, 1996, pp. 8-9. The first performance of the play was given in March 1772.

52 Here we might compare Lessing's observation in chapter 3 of the Laocoön that 'the works of both the painter and the sculptor are created not merely to be given a glance but to be contemplated - contemplated repeatedly and at length' and Kant's recognition in $\S 12$ of the Critique of the Power of Judgment (1790) that 'We linger over the consideration of the beautiful because this consideration strengthens and reproduces itself'. See Lessing, Laocoön, p. 19, and I. Kant, Critique of the Power of Judgment, transl. P. Guyer and E. Matthews, Cambridge, Cambridge University Press, 2000, p. 107. 